\title{
The Effect of Sowing Date and Harvest Time on Leafy Greens of Quinoa (Chenopodium quinoa Willd.) Yield and Selected Nutritional Parameters
}

\author{
Katarzyna Adamczewska-Sowińska ${ }^{1}$ (D), Józef Sowiński ${ }^{2, *(D)}$ and Anna Jama-Rodzeńska ${ }^{2}$ (D) \\ 1 Department of Horticulture, Wroclaw University of Environmental and Life Sciences, \\ 50-375 Wrocław, Poland; katarzyna.adamczewska-sowinska@upwr.edu.pl \\ 2 Institute of Agroecology and Crop Production, Wroclaw University of Environmental and Life Sciences, \\ 50-375 Wrocław, Poland; anna.jama@upwr.edu.pl \\ * Correspondence: jozef.sowinski@upwr.edu.pl
}

Citation: Adamczewska-Sowińska, K.; Sowiński, J.; Jama-Rodzeńska, A. The Effect of Sowing Date and Harvest Time on Leafy Greens of Quinoa (Chenopodium quinoa Willd.) Yield and Selected Nutritional Parameters. Agriculture 2021, 11, 405. https://doi.org/10.3390/ agriculture11050405

Academic Editor: Lorenzo Barbanti

Received: 20 March 2021

Accepted: 25 April 2021

Published: 30 April 2021

Publisher's Note: MDPI stays neutral with regard to jurisdictional claims in published maps and institutional affiliations.

Copyright: (C) 2021 by the authors. Licensee MDPI, Basel, Switzerland. This article is an open access article distributed under the terms and conditions of the Creative Commons Attribution (CC BY) license (https:/ / creativecommons.org/licenses/by/ $4.0 /)$.
Abstract: In 2015-2017, field experiments were conducted, in two facilities of the Wroclaw University of Environmental and Life Sciences: at the Research and Didactic Station in Psary $\left(51^{\circ} 19^{\prime} 08^{\prime \prime} \mathrm{N}\right.$, $\left.17^{\circ} 03^{\prime} 37^{\prime \prime} \mathrm{E}\right)$ and in the plots of the Department of Crop Production in Pawlowice $\left(51^{\circ} 17^{\prime} 32^{\prime \prime} \mathrm{N}\right.$, $17^{\circ} 11^{\prime} 72^{\prime \prime} \mathrm{E}$ ). The research aimed to evaluate fresh biomass yield and selected quality parameters of quinoa grown as a green leafy vegetable. The study was conducted on two soils: medium (clay soil texture) and light (sand soil texture), sowing quinoa in spring and summer periods. On both soils, quinoa was harvested 5 times at each sowing date. The yields of fresh plant biomass, basic morphological characteristics and certain quality traits were compared. All experimental factors had a significant effect on quinoa fresh biomass yield. On light soil, quinoa yielded 4 times lower than on medium soil, and its cultivation posed a high risk, especially at the summer sowing date. The experimental factors used had the greatest effect on macronutrient content. Growing quinoa on medium soil yielded biomass with higher $\mathrm{K}, \mathrm{Mg}$, Ca and $\mathrm{N}-\mathrm{NO}_{3}$ concentration, while spring sown plants had higher $\mathrm{K}$ and $\mathrm{N}-\mathrm{NO}_{3}$ concentration. Harvesting date had the greatest effect on the change in nutritional values. Potassium content decreased as the harvest date was delayed, and $\mathrm{N}-\mathrm{NO}_{3}$ content decreased gradually until the fourth harvest date. The results showed that quinoa should be harvested as a green leafy vegetable when it reaches a height of $20-30 \mathrm{~cm}$; biomass production is then at $500-1000 \mathrm{~g}$ per $\mathrm{m}^{2}$, potassium content is less than $10 \mathrm{~g}$ per $100 \mathrm{~g}$ dry matter and $\mathrm{N}-\mathrm{NO}_{3}$ content is less than $100 \mathrm{mg} 100^{-1} \mathrm{f.m}$.

Keywords: quinoa; biomass yield; biological value; carotenoids; polyphenols; minerals ratio

\section{Introduction}

The genus Chenopodium is the most numerous in the Chenopodiaceae family, with a representation of 250 species widely distributed throughout the world [1]. Quinoa (Chenopodium quinoa Willd.) is one of them, cultivated as a pseudo cereal since ancient times [2]. In the pre-Columbian period, quinoa was known from central Chile to northern Colombia $[3,4]$.

In the last 60 years, there has been increasing interest in the use and cultivation of quinoa due to its nutritional value. Adaptation and acclimatization studies on this species have been carried out in 80 countries worldwide [5], while the current area under cultivation for seed is small at 185,000 ha (mainly in Bolivia, Peru and Ecuador) [6]. Genetic diversity and high adaptability to different growing conditions facilitate the expansion of cultivation of this species. Jacobsen [2] referring to quinoa reports that its cultivation is possible from the sea level up to $4000 \mathrm{~m}$ above sea level, from $40^{\circ}$ south latitude to $2^{\circ}$ north latitude, from cool to tropical climates (quinoa can withstand a temperature range from $-4-38^{\circ} \mathrm{C}$ ), from extremely dry climates and a rainfall of 100-200 $\mathrm{mm}$ annually to a relative humidity of $88 \%$. 
The economic importance of quinoa is not only due to the possibility of using the seeds as a food product characterized by a similar composition and use as consumer cereals. The species can also be managed as a leafy vegetable with high nutritional value and similar uses, such as, for example, spinach [7]. Previously, species from the quinoa family have been used for food as vegetables, mainly species that are semi-weeds or weeds, such as Chenopodium pallidicaule Aellen, Chenopodium berlandieri Moq. ssp. Nuttalliae (Saff.) and Chenopodium album L., harvested at early developmental stages [5,8,9]. Cutting the apical part of the plant at the beginning of inflorescence formation was also practiced. This method of harvesting was often used (to a lesser extent also nowadays) in family farms in Mexico, not only for quinoa cultivation, but also for other plant species, and has been called quelite [10]. Quelite is evaluated as a valuable source of nutrients and food particularly rich in protein, amino acids, minerals $(\mathrm{Ca}, \mathrm{Mg}, \mathrm{Zn})$, vitamins $(\mathrm{E}, \mathrm{C})$ and fiber [10]. Velázquez-Ibarra et al. [11] highlight that quelites are a good source of bioactive compounds, such as phenolic acids (caffeic acid, ferulic acid), flavonoids (quercetin, kaempferol, spinacetin), carotenoids and fatty acids, such as $\alpha$-linolenic with antioxidant activity. The high nutritional value of weeds belonging to the genus quinoa, as well as quinoa harvested during early growth periods, has prompted research on the cultivation of this species as a vegetable. Vazquez et al. [7] found that quinoa leaves are more nutritional, with a more favorable dry matter chemical composition than the seeds of this species. They considered the high protein content with high biological value as distinctive. The amount of protein in quinoa was higher than in spinach, mangold (chard) or broccoli. The mineral content is also high, especially that of magnesium and potassium.

Quinoa leaves or young shoots during the early growing season or the shoots themselves can be used for consumption [7,12]. In a comparative study of three leafy vegetables (quinoa, amaranth, spinach), quinoa leaves had the highest content of protein, the lowest content of carbohydrates, and had all essential amino acids and minerals [13]. In conclusion, the authors found that quinoa was more similar to amaranth than to spinach in terms of chemical composition. Mlakar et al. [14] report that quinoa leaves, when briefly cooked, are similarly used to amaranth and spinach leaves. This use is also recommended by Paśko et al. [15] and Gawlik-Dziki et al. [16], while indicating that quinoa sprouts are also suitable for consumption. Moreover, for nutritional reasons, they recommend quinoa as a dietary ingredient for vegetarians, for food fortification, and highlight its high antioxidant and anti-cancer activity. Quinoa leaves are used for medicinal purposes due to their analgesic, anti-inflammatory, antiseptic, and wound-healing effects [17].

Despite the above examples, there are few studies on the use of quinoa as a vegetable grown under controlled conditions, as well as in the field, on determining at what date quinoa can be sown and on determining the optimal harvest date [13]. A study conducted in Egypt by Abd El-Samad et al. [12] evaluated the chemical composition of two quinoa varieties compared to spinach, grown in the autumn season (from mid-October), harvested 45 days after sowing.

In general, soil requirements (soil texture, moisture and water capacity and fertility) for quinoa are characterized as low, and the species is ranked as potentially suitable for cultivation under conditions particularly unfavorable for many other agricultural crops, e.g., saline soils with low total precipitation. Studies have been undertaken to assess the suitability of quinoa for cultivation under conditions unfavorable to many crops, such as in Middle East and North Africa (MENA) and Central Asia (CA) [18]. In addition to high nutritive value, adaptive properties such as resistance to high temperatures, soil salinity, poor soil quality, and resistance to water stress are mentioned as beneficial traits of this species $[19,20]$.

The presented study evaluates the effect of different sowing and harvest dates on yield and selected quality parameters of quinoa grown on medium loam and light sandy soil. The research verified the hypothesis of whether quinoa under the moderate climate conditions, without fertilization and irrigation, would produce a high yield of good quality 
young plants. The adopted cultivation method was that of spring and autumn harvest, practiced in the cultivation of many species of leafy vegetables.

\section{Materials and Methods}

Two micro-plot experiments carried out at the Wroclaw University of Environmental and Life Sciences concerned the assessment of the possibility of growing quinoa (white form) under temperate climate conditions, with the aim of harvesting young plants for direct consumption. The research was conducted in 2015-2017, in two facilities of the university: at the Research and Didactic Station in Psary $\left(51^{\circ} 19^{\prime} 08^{\prime \prime} \mathrm{N}, 17^{\circ} 03^{\prime} 37^{\prime \prime}\right.$ E), belonging to the Department of Horticulture, and in the plots of the Department of Crop Production in Pawlowice ( $51^{\circ} 17^{\prime} 32^{\prime \prime} \mathrm{N}, 17^{\circ} 11^{\prime} 72^{\prime \prime}$ E).

In Psary, the field experiment was carried out on chernozems with a calcic level on medium clay soil texture, belonging to the medium soil class (class IIIb-FAO-WRB Gleyic Calcic Chernozems soil) [21,22]. The soil has a humus content of $1.8 \%$, pH 7.25, available form of phosphorus $55 \mathrm{mg} \mathrm{dm}^{-3}$, available form of potassium $85 \mathrm{mg} \mathrm{dm}^{-3}$ and magnesium $99 \mathrm{mg} \mathrm{dm}^{-3}$. In Pawłowice, the experiment was carried out on sand textured soil belonging to the light soil type (class V-FAO-WRB Brunic Arenosols soil) [21,23], characterized by humus content of $1.1 \%$ and slightly acidic $\mathrm{pH}$ (6.0). The soil has a high available phosphorus $77 \mathrm{mg} \mathrm{dm}^{-3}$, and medium available form of potassium $41 \mathrm{mg} \mathrm{dm}^{-3}$ and magnesium $11 \mathrm{mg} \mathrm{dm}^{-3}$

Total available water (TAW) retention in the arable layer (in the range Pf 2.0-4.2) depends on the granulometric composition and ranges from $9.76 \% \mathrm{v}$ (for light soils) to $22.50 \% \mathrm{v}$ for medium soils [24].

The experiment was established using the randomized sub-block method, at a plot size of $0.9 \mathrm{~m}^{2}$ in 3 replications. Factor I compared dates of quinoa sowing-spring and summer. Factor II concerned the cultivation site (soil type), while factor III the harvest date (Figure 1). Harvest dates for spring and summer sown quinoa on both soils are shown in Table 1. Quinoa biomass yield and morphological measurement made on 180 samples (3 years, 2 soil types, 2 sowing date, 5 harvest date, 3 replication: $n=180$ ). Chemical biomass analysis was performed on combined samples from 3 replications: $n=60$ ).

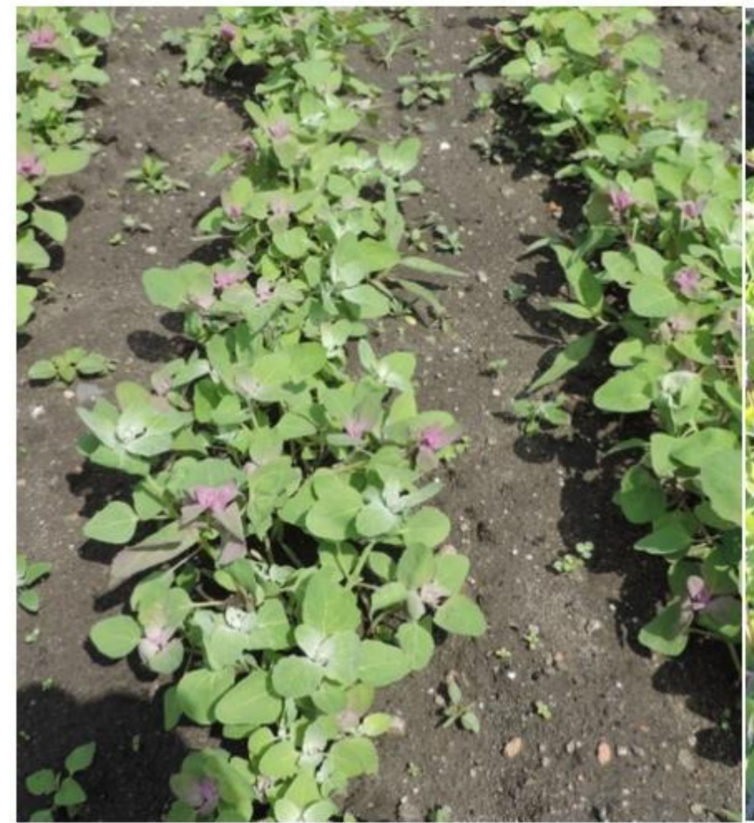

Quinoa before $1^{\text {st }}$ harvest

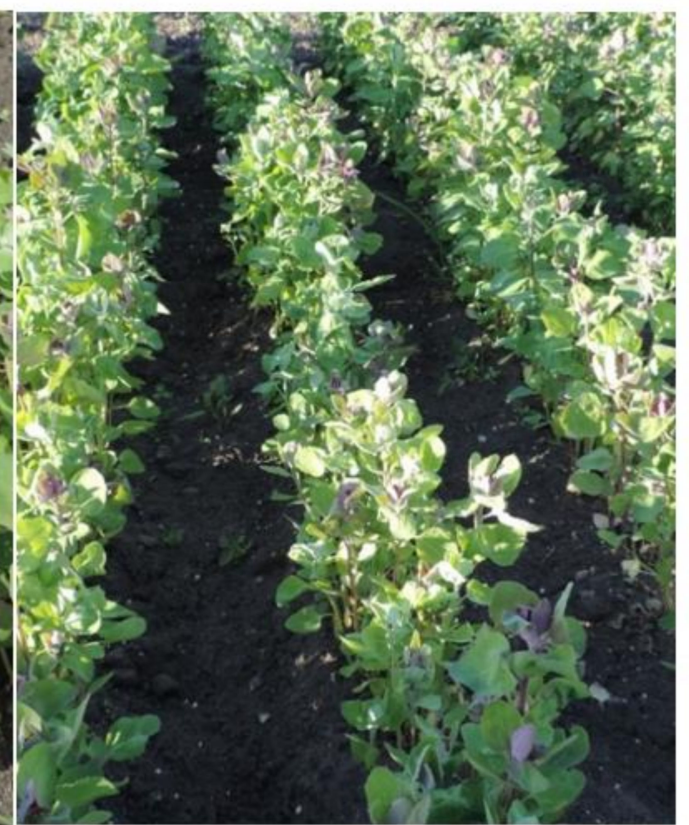

Quinoa before $4^{\text {th }}$ harvest

Figure 1. Quinoa experiment on medium soil. 
Table 1. Quinoa harvest date and number of days from sowing to harvest (in brackets).

\begin{tabular}{|c|c|c|c|c|c|c|c|c|c|c|c|c|}
\hline \multirow{3}{*}{ Harvest Date } & \multicolumn{6}{|c|}{ Spring Sowing } & \multicolumn{6}{|c|}{ Late Summer Sowing } \\
\hline & \multicolumn{3}{|c|}{ Medium Soil } & \multicolumn{3}{|c|}{ Light Soil } & \multicolumn{3}{|c|}{ Medium Soil } & \multicolumn{3}{|c|}{ Light Soil } \\
\hline & 2015 & 2016 & 2017 & 2015 & 2016 & 2017 & 2015 & 2016 & 2017 & 2015 & 2016 & 2017 \\
\hline 1 harvest date & $\begin{array}{c}25.05 \\
(38)\end{array}$ & $\begin{array}{c}23.05 \\
(35)\end{array}$ & $\begin{array}{c}04.06 \\
(40)\end{array}$ & $\begin{array}{c}25.05 \\
(38)\end{array}$ & $\begin{array}{c}24.05 \\
(36)\end{array}$ & $\begin{array}{c}04.06 \\
(40)\end{array}$ & $\begin{array}{c}25.08 \\
(23)\end{array}$ & $\begin{array}{c}31.08 \\
(30)\end{array}$ & $\begin{array}{c}07.09 \\
(36)\end{array}$ & - & $\begin{array}{c}31.08 \\
(30)\end{array}$ & $\begin{array}{c}01.09 \\
(30)\end{array}$ \\
\hline 2 harvest date & $\begin{array}{c}01.06 \\
(45)\end{array}$ & $\begin{array}{c}30.05 \\
(42)\end{array}$ & $\begin{array}{c}11.06 \\
(47)\end{array}$ & $\begin{array}{c}01.06 \\
(45)\end{array}$ & $\begin{array}{c}30.05 \\
(42)\end{array}$ & $\begin{array}{c}11.06 \\
(47)\end{array}$ & $\begin{array}{c}31.08 \\
(29)\end{array}$ & $\begin{array}{c}07.09 \\
(37)\end{array}$ & $\begin{array}{c}14.09 \\
(43)\end{array}$ & - & $\begin{array}{c}07.09 \\
(37)\end{array}$ & $\begin{array}{c}07.09 \\
(36)\end{array}$ \\
\hline 3 harvest date & $\begin{array}{c}08.06 \\
(52)\end{array}$ & $\begin{array}{c}06.06 \\
(49)\end{array}$ & $\begin{array}{c}18.06 \\
(54)\end{array}$ & $\begin{array}{c}08.06 \\
(52)\end{array}$ & $\begin{array}{c}06.06 \\
(49)\end{array}$ & $\begin{array}{c}18.06 \\
(54)\end{array}$ & $\begin{array}{c}07.09 \\
(36)\end{array}$ & $\begin{array}{c}15.09 \\
(45)\end{array}$ & $\begin{array}{c}22.09 \\
(51)\end{array}$ & - & $\begin{array}{c}14.09 \\
(44)\end{array}$ & $\begin{array}{c}14.09 \\
(43)\end{array}$ \\
\hline 4 harvest date & $\begin{array}{c}15.06 \\
(59)\end{array}$ & $\begin{array}{c}13.06 \\
(56)\end{array}$ & $\begin{array}{c}26.06 \\
(62)\end{array}$ & $\begin{array}{c}15.06 \\
(59)\end{array}$ & $\begin{array}{c}13.06 \\
(56)\end{array}$ & $\begin{array}{c}26.06 \\
(62)\end{array}$ & $\begin{array}{c}16.09 \\
(45)\end{array}$ & $\begin{array}{c}21.09 \\
(51)\end{array}$ & $\begin{array}{c}28.09 \\
(57)\end{array}$ & - & $\begin{array}{c}21.09 \\
(51)\end{array}$ & $\begin{array}{c}21.09 \\
(50)\end{array}$ \\
\hline 5 harvest date & $\begin{array}{c}22.06 \\
(66)\end{array}$ & $\begin{array}{c}21.06 \\
(64)\end{array}$ & $\begin{array}{c}03.07 \\
(69)\end{array}$ & $\begin{array}{c}22.06 \\
(66)\end{array}$ & $\begin{array}{c}20.06 \\
(63)\end{array}$ & $\begin{array}{c}03.07 \\
(69)\end{array}$ & $\begin{array}{c}21.09 \\
(50)\end{array}$ & $\begin{array}{c}28.09 \\
(58)\end{array}$ & $\begin{array}{c}05.10 \\
(64)\end{array}$ & - & $\begin{array}{c}28.09 \\
(58)\end{array}$ & $\begin{array}{c}28.09 \mathrm{t} \\
(57)\end{array}$ \\
\hline
\end{tabular}

Quinoa seeds were hand sown in the field, in rows, spaced $30 \mathrm{~cm}$ apart. There was $0.3 \mathrm{~g}$ of seed per 1 linear meter of row $\left(0.9 \mathrm{~g}\right.$ per $1 \mathrm{~m}^{2}$ i.e., $9 \mathrm{~kg}$ per ha), 450 seeds per $\mathrm{m}^{2}$. In both soils, the sowing dates were 17 April and 2 August in 2015, 18 April and 1 August in 2016, and 25 April and 2 August in 2017.

Field preparation for the experiment consisted of deep pre-winter ploughing, followed by cultivation and harrowing in spring. Before sowing, the soil surface was carefully prepared and levelled to ensure uniform seed sowing to a depth of $0.5 \mathrm{~cm}$ and even plant emergence. The methodology of the experiment did not provide for fertilization before and during the cultivation. The experiments were established on soils rich in nutrients. In addition, the vegetation period of quinoa was a maximum of about 2 months and the expected biomass production was low; therefore, no fertilization was applied before the establishment of the experiment. Depending on moisture conditions, directly after sowing until emergence, the experiment was irrigated (especially in the summer sowing date), by sprinkling (2-3 times). No irrigation was applied after emergence. Depending on the necessity, weeds were removed mechanically and manually.

During harvest, the height of plants, the diameter of the shoot at the base, the number of leaves and the weight of one plant were determined. All quinoa plants were harvested by manual cutting at $1 \mathrm{~cm}$ height from $0.9 \mathrm{~m}^{2}$ in three replications. At each date, plants were harvested from successive plots. The quinoa did not regrow after cutting. The yield of fresh plants per $1 \mathrm{~m}^{2}$ was then determined.

At each harvest date, from both soil and sowing dates, quinoa plants were assayed for: the content of dry mass - using the weighing method (PN-90/A-75101/03) [25]; of vitamin C-using the titration method (PN-90/A-75101/11) [26]; of carotenoids—using the colorimetric method; of polyphenols-Folina-Ciocalteu method [27]; of the chlorophyll $\mathrm{a}+\mathrm{b}$ colorimetric (spectrophotometric) method. Dried plant material $(0.4 \mathrm{~g})$ was shaken in $100 \mathrm{~mL}$ of $2 \%$ acetic acid. After filtration, $5 \mathrm{~mL}$ was taken for $\mathrm{Mg}$ determination. After staining with titanium yellow, the concentration was read on a colorimeter at the wave length $555 \mathrm{~nm}$. P determination, $20 \mathrm{~mL}$ of the percolated sample is taken. After staining in a mixture with ammonium metavanadium, the concentration on the colorimeter is read (wave length $470 \mathrm{~nm}$ ).

$\mathrm{Ca}$ and $\mathrm{K}$ are determined on a flame photometer using percolated samples. Concentration was calculated using standards from the curve.

Nitrate content was analyzed by the Bremner microdistillation method according to the Starck modification after extraction in $2 \%$ acetic acid solution [28].

At the site of the experiment, air temperature was recorded continuously using an electronic recorder Temp Logger AZ 8828 and precipitation measurements were taken with a Hellmann rain gauge.

Based on the daily average air temperature, the number of heat units (basal temperature $3{ }^{\circ} \mathrm{C}$ ) from sowing to harvest was calculated according to Formula (1) as an accumulated growing degree day (AGDD) [2,29]. 


$$
\text { AGDD }=\sum_{i=0}^{n}(T \text { average }-T \text { base })
$$

Higher temperature totals were recorded annually for the summer growing season of quinoa, compared to the spring-sown crop (Figure 2). These differences in successive years for the first quinoa harvest date were $42.2 \%, 43.4 \%$ and $15.5 \%$ on average, and for the fifth harvest date in 2015 (27.3\%) and in 2016 (11.9\%). The exception was 2017, where heat accumulation in the spring-sown crop, for the longest growing crop, was $15.3 \%$ greater. It was also noted that where the crop was grown on medium soil, the sum of temperatures was greater than when the quinoa was grown on light soil.

Weather conditions during the experiment were presented in the form of the hydrothermal coefficient of water supply according to the Sielianinov index $(K)[30,31]$.

The index was calculated according to Equation (2) and presented in Table 2:

$$
K=\frac{\sum_{i=0}^{n}(P \cdot 10)}{\sum_{i=0}^{n} T}
$$

$K$-Sielianinov index, $P$-daily precipitation in the respective period, $T$-daily temperatures in the respective period.

If $K$ value was: $<0.5=$ drought, $0.5-1.0=$ semi-drought, $1.0-1.5=$ optimal moisture, $>1.5=$ excessive moisture.

The Sielianinov hydrothermal indices calculated for each cropping period indicate hydrologically difficult conditions for plant growth in 2015-2016. Comparing thermal with water conditions, in 2015, both cropping sites experienced semi-drought in spring and drought in summer (Table 2). On the light soil, where the $K$ factor in summer ranged from $0.06-0.3$, the crop was liquidated, due to plant death after emergence. In 2016, after spring sowing throughout the quinoa growing season, the medium soil experienced semidrought ( $K$ ranging from $0.47-0.97$ ), while the light soil experienced drought ( $K$ ranging from $0.18-0.43$ ). After summer sowing, by the third harvest date, drought was observed at both crop sites, while semi-drought was observed at crops after one week and two weeks. Hydrothermal conditions were most favorable in 2017. On the medium soil, optimal or near-optimal moisture conditions ( $K$ ranging from $0.89-1.21$ ) were found throughout the quinoa crop. On the light soil, semi-drought prevailed during the earlier cultivation period, while the summer-autumn period was characterized by optimal moisture conditions.

From April to October, in all years of the study, the average air temperature was higher than the multi-year average on both soil types (Table 3). In 2015, precipitation was below the multi-year total, and in 2017, it was higher. At the level of the multi-year total, the amount of precipitation was at a similar level in 2016.

\begin{tabular}{|c|c|c|c|c|c|c|c|c|c|c|}
\hline \multirow{3}{*}{ Year } & \multicolumn{5}{|c|}{ Spring Sowing } & \multicolumn{5}{|c|}{ Summer Sowing } \\
\hline & \multicolumn{5}{|c|}{ Harvest Date } & \multicolumn{5}{|c|}{ Harvest Date } \\
\hline & $1 *$ & 2 & 3 & 4 & 5 & 1 & 2 & 3 & 4 & 5 \\
\hline \multicolumn{11}{|c|}{ Medium soil } \\
\hline 2015 & 0.61 & 0.62 & 0.55 & 0.68 & 0.79 & 0.03 & 0.03 & 0.12 & 0.18 & 0.16 \\
\hline 2016 & 0.67 & 0.54 & 0.51 & 0.47 & 0.97 & 0.30 & 0.39 & 0.33 & 0.73 & 0.66 \\
\hline 2017 & 1.09 & 1.09 & 1.04 & 0.89 & 1.21 & 0.95 & 0.96 & 0.92 & 1.03 & 1.03 \\
\hline \multicolumn{11}{|c|}{ Light soil } \\
\hline 2015 & 0.53 & 0.44 & 0.54 & 0.73 & 0.83 & 0.06 & 0.08 & 0.17 & 0.30 & 0.28 \\
\hline 2016 & 0.26 & 0.24 & 0.20 & 0.18 & 0.43 & 0.43 & 0.46 & 0.38 & 0.74 & 0.68 \\
\hline 2017 & 0.89 & 0.73 & 0.62 & 0.52 & 0.92 & 1.20 & 1.13 & 1.13 & 1.07 & 1.15 \\
\hline
\end{tabular}

Table 2. Hydrothermal Sielianinov index $(K)$ during the quinoa growing seasons.

\footnotetext{
* explanation in Table 1 .
} 

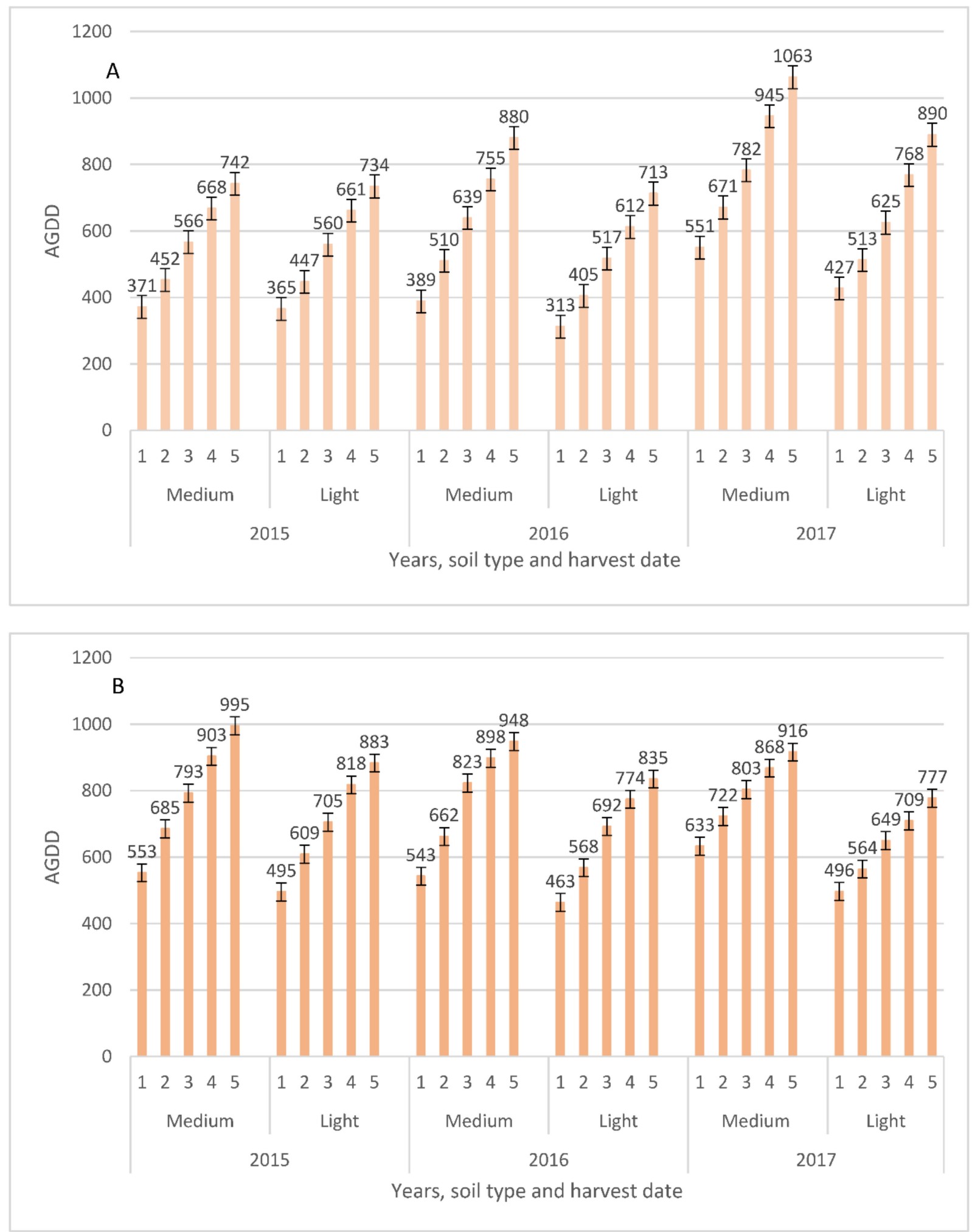

Figure 2. Differences of Accumulated Growing Degree Days during the quinoa vegetation on medium and light soil. (A) Spring sowing date, (B) Summer sowing date. 
Table 3. Average temperature $\left({ }^{\circ} \mathrm{C}\right)$ and rainfall sum $(\mathrm{mm})$ for quinoa vegetation period.

\begin{tabular}{|c|c|c|c|c|c|c|c|c|}
\hline \multirow{2}{*}{ Months } & \multicolumn{4}{|c|}{ Temperature $\left({ }^{\circ} \mathrm{C}\right)$} & \multicolumn{4}{|c|}{ Rainfall (mm) } \\
\hline & 2015 & 2016 & 2017 & Multi Years Average & 2015 & 2016 & 2017 & Multi Years Average \\
\hline \multicolumn{9}{|c|}{ Medium soil } \\
\hline April & 9.2 & 10.7 & 9.1 & 8.2 & 16.3 & 39.2 & 15.0 & 37.0 \\
\hline May & 13.5 & 17.4 & 16.4 & 13.5 & 26.8 & 26.0 & 54.3 & 57.0 \\
\hline June & 16.8 & 21.0 & 20.7 & 16.3 & 66.3 & 69.2 & 73.5 & 79.0 \\
\hline July & 20.3 & 21.5 & 21.1 & 18.1 & 53.2 & 128.5 & 183.5 & 91.0 \\
\hline August & 25.1 & 20.5 & 21.5 & 17.8 & 2.1 & 19.1 & 38.0 & 64.0 \\
\hline September & 16.6 & 18.5 & 14.4 & 13.6 & 16.4 & 57.3 & 69.5 & 51.0 \\
\hline October & 9.3 & 9.0 & 12.0 & 8.9 & 19.4 & 71.6 & 67.8 & 38.0 \\
\hline Mean/Sum & 15.8 & 16.9 & 16.5 & 13.8 & 200.5 & 410.9 & 501.6 & 417.0 \\
\hline \multicolumn{9}{|c|}{ Light soil } \\
\hline April & 8.9 & 8.7 & 7.9 & 8.9 & 15.8 & 46.4 & 57.0 & 33.6 \\
\hline May & 13.5 & 15.3 & 14.2 & 14.4 & 21.0 & 5.3 & 24.1 & 54.1 \\
\hline June & 16.6 & 18.6 & 18.5 & 17.3 & 73.3 & 44.6 & 52.5 & 67.4 \\
\hline July & 20.3 & 19.5 & 19.0 & 19.6 & 55.6 & 114.3 & 112.2 & 78.9 \\
\hline August & 22.7 & 17.9 & 19.4 & 18.6 & 5.6 & 27.1 & 43.6 & 65.3 \\
\hline September & 15.1 & 16.4 & 13.3 & 13.7 & 23.2 & 44.7 & 65.7 & 44.9 \\
\hline October & 8.4 & 8.5 & 12.0 & 9.1 & 20.0 & 83.8 & 71.4 & 33.7 \\
\hline Mean/Sum & 15.1 & 15.0 & 14.9 & 14.5 & 214.5 & 366.2 & 426.5 & 377.9 \\
\hline
\end{tabular}

The results of the study, both biometric traits as well as biomass yield and selected nutritional traits of quinoa, were statistically processed by two-way ANOVA analysis of variance, using Tukey's test for a significance level of $p=0.05$. Experimental factors: sowing date, soil type and harvest date were introduced as fixed effect, and replications and years were assumed as random effect. Lowercase letters denote homogeneous groups of means. Calculations were performed using the STATISTICA 13.1 software package (Stat Soft, Poland).

\section{Results}

A statistical analysis of the results of the experiments showed the influence of the investigated factors on quinoa growth and yield (Table 4). We found that plants of this species grown on medium soil were characterized on average by significantly greater height (by $56.7 \%$ ), shoot diameter (by $46.9 \%$ ) and weight per plant (by $89.2 \%$ ). They also produced 4 times higher yield compared to plants grown on light soil.

Cultivation dates did not have such a differential effect on quinoa growth. The only significant difference was in the number of leaves. Plants grown at the later date produced $16.4 \%$ more of them. They also had slightly larger shoot diameter and weight per plant. A significantly higher yield (by 56\%) was found by sowing the seeds in spring.

The harvest date had a highly significant effect on growth and yield of quinoa. On average, plants harvested at the first date, i.e., after 33 days of sowing, were characterized by the lowest values of the analyzed traits. As harvesting was delayed by successive weeks, plant height, shoot diameter, number of leaves, and plant unit weight increased. It was noted, however, that differences in shoot height and diameter between plants from the last two harvests were not significantly different. There was also no significant difference between the yields obtained on these dates.

Considering the interaction of factors, it was estimated that the highest fresh weight yield was harvested when quinoa was grown on medium soil under spring sowing. Cultivation on the same soil type but in the second evaluated period resulted in a yield decrease of $44.1 \%$. The spring as well as the summer sowing of this species on light soil caused, on the other hand, a 4.4-fold and 5.7-fold decrease in yield compared to the highest yield. 
Table 4. The effect of soil type, sowing date and harvest date on quinoa biometrics parameters and biomass yield. Average from years 2015-2017.

\begin{tabular}{|c|c|c|c|c|c|c|}
\hline $\begin{array}{l}\text { Experiment } \\
\text { Treatment }\end{array}$ & $\begin{array}{l}\text { Experiment } \\
\text { Treatment }\end{array}$ & $\begin{array}{l}\text { Stem Length } \\
(\mathrm{cm})\end{array}$ & $\begin{array}{c}\text { Stem Diameter } \\
(\mathrm{mm})\end{array}$ & Leaf Number & $\begin{array}{l}\text { Weight of One } \\
\text { Plant (g) }\end{array}$ & $\begin{array}{l}\text { Weight from } \\
1 \mathrm{~m}^{2}(\mathrm{~g})\end{array}$ \\
\hline \multicolumn{7}{|c|}{ Soil and sowing date interaction } \\
\hline \multirow{2}{*}{ Medium } & Spring sowing & 30.3 & $4.8 \mathrm{a}$ & 12.5 & 11.9 & $1388.6 a$ \\
\hline & $\begin{array}{c}\text { Summer } \\
\text { sowing }\end{array}$ & 24.9 & $4.6 \mathrm{a}$ & 14.6 & 12.9 & $776.9 \mathrm{~b}$ \\
\hline \multirow{2}{*}{ Light } & Spring sowing & 17.2 & $2.9 \mathrm{c}$ & 11.8 & 5.1 & $317.5 \mathrm{c}$ \\
\hline & $\begin{array}{c}\text { Summer } \\
\text { sowing }\end{array}$ & 18.6 & $3.7 \mathrm{~b}$ & 13.8 & 8.6 & $244.7 \mathrm{c}$ \\
\hline \multicolumn{2}{|c|}{ Significance } & $p=0.086$ & $p=0.008$ & $p=0.938$ & $p=0.401$ & $p=0.003$ \\
\hline \multicolumn{7}{|c|}{ Soil and harvest date interaction } \\
\hline \multirow{7}{*}{ Medium } & 1 * & 11.7 & 3.2 & 9.1 & $2.8 \mathrm{e}$ & 336.3ef \\
\hline & 2 & 19.5 & 4.3 & 12.7 & $7.3 \mathrm{cde}$ & $783.4 \mathrm{~cd}$ \\
\hline & 3 & 29.1 & 4.6 & 12.7 & $9.8 \mathrm{bc}$ & $946.1 d$ \\
\hline & 4 & 37.7 & 5.7 & 13.8 & $17.0 \mathrm{~b}$ & $1539.0 \mathrm{~b}$ \\
\hline & 5 & 40.5 & 5.7 & 17.9 & $22.6 a$ & $1958.7 a$ \\
\hline & 1 & 7.4 & 2.1 & 9.5 & $2.3 c$ & $103.9 \mathrm{c}$ \\
\hline & 2 & 11.6 & 2.9 & 10.8 & $3.8 \mathrm{c}$ & $184.8 \mathrm{bc}$ \\
\hline \multirow[t]{3}{*}{ Light } & 3 & 17.2 & 3.1 & 13.0 & $5.4 \mathrm{bc}$ & $257.3 b c$ \\
\hline & 4 & 24.1 & 3.8 & 13.7 & $9.6 \mathrm{ba}$ & $388.0 \mathrm{bc}$ \\
\hline & 5 & 28.5 & 4.3 & 16.1 & $11.4 \mathrm{a}$ & $507.9 \mathrm{ba}$ \\
\hline \multicolumn{2}{|c|}{ Significance } & $p=0.105$ & $p=0.672$ & $p=0.614$ & $p=0.030$ & $p<0.001$ \\
\hline \multicolumn{7}{|c|}{ Average for soil type } \\
\hline \multicolumn{2}{|c|}{ Medium } & $27.9 a$ & $4.7 \mathrm{a}$ & 12.4 & $12.3 a$ & $1165.7 \mathrm{a}$ \\
\hline \multicolumn{2}{|c|}{ Light } & $17.8 \mathrm{~b}$ & $3.2 b$ & 12.6 & $6.5 b$ & $288.4 \mathrm{~b}$ \\
\hline \multicolumn{2}{|c|}{ Significance } & $p<0.001$ & $p<0.001$ & $p=0.303$ & $p<0.001$ & $p<0.001$ \\
\hline \multicolumn{7}{|c|}{ Average for sowing date } \\
\hline \multicolumn{2}{|c|}{ Spring sowing } & 23.7 & 3.8 & $12.2 b$ & 8.5 & $834.6 a$ \\
\hline \multicolumn{2}{|c|}{ Summer sowing } & 22.0 & 4.2 & $14.2 \mathrm{a}$ & 10.9 & $535.0 \mathrm{~b}$ \\
\hline \multicolumn{2}{|c|}{ Significance } & $p=0.420$ & $p=0.146$ & $p=0.007$ & $p=0.118$ & $p=0.010$ \\
\hline \multicolumn{7}{|c|}{ Average for harvest date } \\
\hline & & $9.5 \mathrm{~d}$ & $2.6 c$ & $9.3 \mathrm{~d}$ & $2.5 \mathrm{~d}$ & $220.1 c$ \\
\hline & & $15.9 \mathrm{c}$ & $3.7 \mathrm{~b}$ & $11.8 \mathrm{c}$ & $5.6 \mathrm{~cd}$ & $484.1 \mathrm{bc}$ \\
\hline & & $23.2 b$ & $3.8 \mathrm{~b}$ & $12.9 b$ & $7.6 c$ & $633.0 \mathrm{c}$ \\
\hline & & $30.9 \mathrm{~s}$ & $4.7 \mathrm{a}$ & $13.7 \mathrm{~b}$ & $13.3 b$ & $963.5 a$ \\
\hline & & $35.1 \mathrm{a}$ & $5.0 \mathrm{a}$ & $17.1 \mathrm{a}$ & $17.5 \mathrm{a}$ & $1233.3 a$ \\
\hline Sig & cance & $p<0.001$ & $p<0.001$ & $p<0.001$ & $p<0.001$ & $p<0.001$ \\
\hline
\end{tabular}

* explanation in Table 1,p-significance; similar small letter within each column indicate no significance differences between treatments $(p>0.05)$ based on results of ANOVA.

Statistical analysis on the interaction of factors such as soil type and harvest dates showed that plants grown on light soil, harvested at the first and second dates, and on medium soil from the first harvest date had the lowest unit weight. Quinoa plants grown on light soil and harvested on the third harvest date were in the same homogeneous group. Plants harvested on the last date on medium soil had the highest weight $(22.6 \mathrm{~g})$. In this location, an earlier harvest date of one week brought a $24.8 \%$ decrease in unit weight, but it too was significantly higher than in the other sites. Similar relationships apply to quinoa yield. The highest fresh weight yield $\left(1958.7 \mathrm{~g} \mathrm{~m}^{-2}\right)$ was harvested on medium soil at the last date under study. Accelerating harvest by one week resulted in a significant $21.4 \%$ decrease in yield. The lowest yields, remaining in the same homogeneous group, were observed in plots on light soil using the harvest dates from I to IV and on medium soil at the first harvest date. Here, there was a decrease in relation to the highest yield by $87 \%$ on average. 
Accumulated growing degree days were strongly correlated with biometric quinoa parameters (Figure 3 ). The increase in heat units was positively correlated with the stem length $(r=0.811)$, stem diameter $(r=0.720)$, leaf numbers $(r=0.614)$, weight of one plant (0.548) and weight of biomass from $1 \mathrm{~m}^{2}(\mathrm{r}=0.719)$.

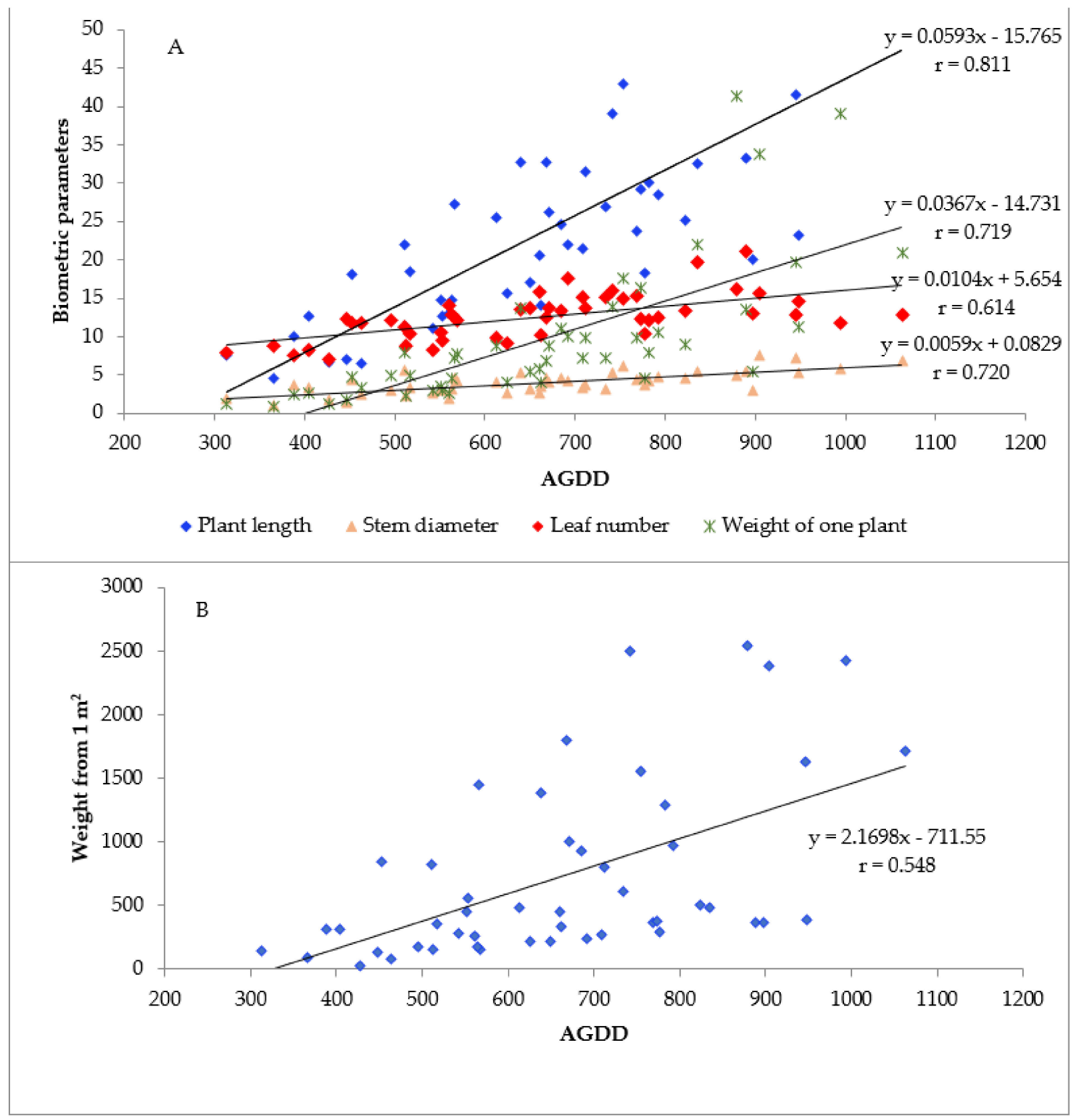

Figure 3. Effect of thermal condition presented in accumulated growing degree days of the quinoa biometric parameters (A) and fresh biomass yield (B).

The results of the chemical analysis of quinoa plants showed that their dry matter content depended on sowing date and harvest date and on the interaction of factors, such as soil type and cultivation period (Table 5). Plants sown in spring, especially on light soil, exhibited more dry matter. Shifting the harvest date increased the dry matter content from $10.9-11.4 \%$ at the 1 st and 2 nd dates to $13.4-14.1 \%$ at the 4 th and 5 th dates. There was no effect of the experiment parameters on the content of polyphenols. The plants sown in spring accumulated the most chlorophyll $a+b$, especially on medium soil. Statistical 
analysis showed, however, that their accumulation also occurred on light soil. Cultivation on light soil caused an increase in carotenoids content. The highest content of carotenoids was determined on this site in plants sown at the beginning of August. Quinoa from spring sowing contained significantly more, on average by $17.2 \%$, vitamin $C$ than that from a later sowing. In plants sown in spring on medium soil and in spring and summer on light soil,

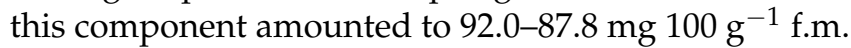

The study showed that the concentration of nutrients in the soil influenced their accumulation. Quinoa grown on medium soil accumulated significantly more magnesium (by $26.6 \%$ ) and, at the same time, less phosphorus (by 16.6\%) in its biomass compared to that grown on light soil (Table 6).

Plant samples from medium soil also showed more potassium and calcium, but these differences were not statistically proven. In this site, quinoa also accumulated significantly more nitrates, by $40.6 \%$.

Table 5. The effect of soil type, sowing date and harvest date on quinoa dry matter, chlorophyll, carotenoids, polyphenols and vitamin C content. Average from years 2015-2017.

\begin{tabular}{|c|c|c|c|c|c|c|}
\hline $\begin{array}{l}\text { Experiment } \\
\text { Treatment }\end{array}$ & $\begin{array}{l}\text { Experiment } \\
\text { Treatment }\end{array}$ & $\begin{array}{l}\text { D.M. } \\
\%\end{array}$ & $\begin{array}{l}\text { Chlorophyll a+b } \\
\operatorname{Mg~g}^{-1} \text { f.m.** }\end{array}$ & $\begin{array}{l}\text { Carotenoids } \\
\mu \mathrm{g} \cdot \mathrm{g}^{-1} \text { f.m. }\end{array}$ & $\begin{array}{l}\text { Polyphenols } \\
\text { mg.100 } \mathrm{g}^{-1} \text { f.m. }\end{array}$ & $\begin{array}{c}\text { Vit C } \\
\text { mg.100 } \mathrm{g}^{-1} \\
\text { f.m. }\end{array}$ \\
\hline \multicolumn{7}{|c|}{ Soil and sowing date interaction } \\
\hline \multirow{2}{*}{ Medium } & Spring sowing & $12.6 \mathrm{ab}$ & $0.82 \mathrm{a}$ & $1.46 \mathrm{~b}$ & 131.5 & $92.0 \mathrm{a}$ \\
\hline & $\begin{array}{l}\text { Summer } \\
\text { sowing }\end{array}$ & $12.2 \mathrm{bc}$ & $0.60 c$ & $1.40 \mathrm{~b}$ & 119.2 & $68.8 b$ \\
\hline \multirow{2}{*}{ Light } & Spring sowing & $13.5 \mathrm{a}$ & $0.74 b$ & $1.44 b$ & 107.1 & $87.8 \mathrm{a}$ \\
\hline & $\begin{array}{c}\text { Summer } \\
\text { sowing }\end{array}$ & $11.4 \mathrm{c}$ & $0.70 \mathrm{~b}$ & $1.72 \mathrm{a}$ & 132.4 & $88.5 \mathrm{a}$ \\
\hline \multicolumn{2}{|c|}{ Significance } & $p=0.018$ & $p=0.002$ & $p<0.001$ & $p=0.057$ & $p=0.029$ \\
\hline \multicolumn{7}{|c|}{ Soil and harvest date interaction } \\
\hline \multirow{7}{*}{ Medium } & $1 *$ & 10.8 & 0.68 & 1.43 & 114.2 & 71.5 \\
\hline & 2 & 11.8 & 0.75 & 1.39 & 118.1 & 80.9 \\
\hline & 3 & 13.0 & 0.67 & 1.27 & 137.2 & 92.5 \\
\hline & 4 & 13.2 & 0.75 & 1.57 & 143.4 & 82.3 \\
\hline & 5 & 13.4 & 0.71 & 1.49 & 113.9 & 74.7 \\
\hline & 1 & 11.0 & 0.72 & 1.71 & 105.8 & 83.8 \\
\hline & 2 & 10.9 & 0.69 & 1.41 & 116.1 & 81.1 \\
\hline \multirow[t]{3}{*}{ Light } & 3 & 12.7 & 0.75 & 1.44 & 122.6 & 98.2 \\
\hline & 4 & 13.7 & 0.74 & 1.66 & 119.1 & 90.1 \\
\hline & 5 & 15.0 & 0.72 & 1.55 & 122.6 & 87.0 \\
\hline \multicolumn{2}{|c|}{ Significance } & $p=0.182$ & $p=0.765$ & $p=0.458$ & $p=0.864$ & $p=0.954$ \\
\hline \multicolumn{7}{|c|}{ Average for soil type } \\
\hline \multicolumn{2}{|c|}{ Medium } & 12.4 & 0.71 & $1.43 b$ & 125.4 & 80.4 \\
\hline & & 12.6 & 0.73 & $1.56 a$ & 117.2 & 88.1 \\
\hline \multicolumn{2}{|c|}{ Significance } & $p=0.597$ & $p=0.641$ & $p=0.012$ & $p=0.407$ & $p=0.163$ \\
\hline \multicolumn{7}{|c|}{ Average for sowing date } \\
\hline \multicolumn{2}{|c|}{ Spring sowing } & $13.1 \mathrm{a}$ & $0.78 \mathrm{a}$ & 1.45 & 119.3 & $89.9 a$ \\
\hline \multicolumn{2}{|c|}{ Summer sowing } & $11.9 b$ & $0.64 b$ & 1.53 & 124.5 & $76.7 \mathrm{~b}$ \\
\hline \multicolumn{2}{|c|}{ Significance } & $p=0.002$ & $p<0.001$ & $p=0.126$ & $p=0.596$ & $p=0.016$ \\
\hline \multicolumn{7}{|c|}{ Average for harvest date } \\
\hline & & $10.9 c$ & 0.70 & $1.56 \mathrm{ab}$ & 110.4 & 77.1 \\
\hline & & $11.4 \mathrm{bc}$ & 0.72 & $1.40 \mathrm{bc}$ & 117.2 & 81.0 \\
\hline & & $12.8 \mathrm{ab}$ & 0.71 & $1.35 c$ & 130.5 & 95.1 \\
\hline & & $13.4 \mathrm{a}$ & 0.74 & $1.61 \mathrm{a}$ & 132.4 & 85.9 \\
\hline & & $14.1 \mathrm{a}$ & 0.72 & $1.52 \mathrm{ab}$ & 117.9 & 80.3 \\
\hline Sign & ance & $p=0.002$ & $p=0.915$ & $p=0.003$ & $p=0.559$ & $p=0.258$ \\
\hline
\end{tabular}

* explanation in Table $1,{ }^{* *}$ f.m. fresh mass, $p$-significance; similar small letter within each column indicate no significance differences between treatments $(p>0.05)$ based on results of ANOVA. 
Table 6. The effect of soil type, sowing date and harvest date on quinoa minerals composition and $\mathrm{N}-\mathrm{NO}_{3}$ content. Average from years 2015-2017.

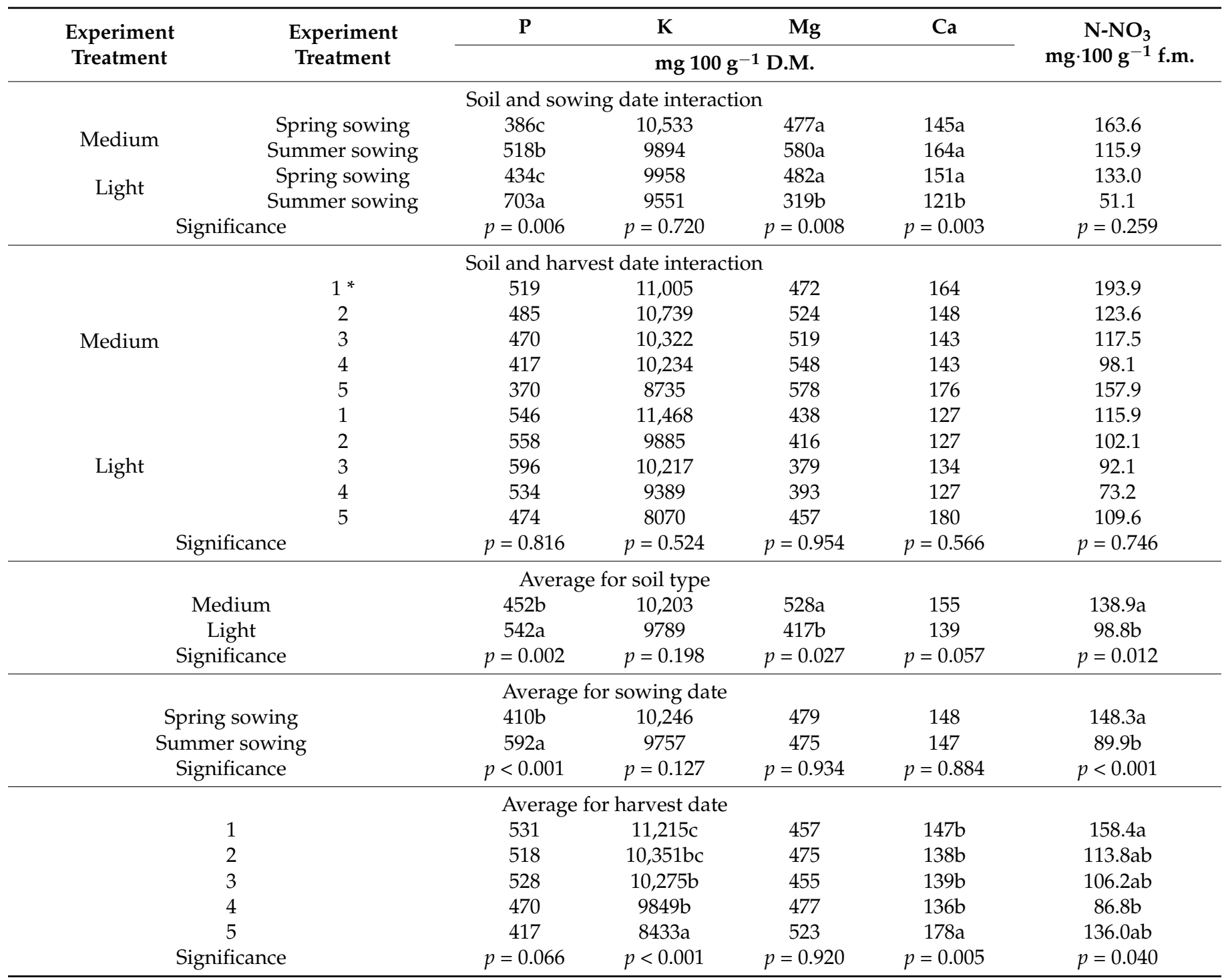

* explanation in Table 1,p-significance; similar small letter within each column indicate no significance differences between treatments $(p>0.05)$ based on results of ANOVA.

A significant effect of sowing date was found only for phosphorus and nitrate contents. Quinoa sown in early August accumulated $44.4 \%$ more $\mathrm{P}$ and $39.4 \%$ less $\mathrm{N}-\mathrm{NO}_{3}$. A gradual delay of harvest resulted in a decrease in potassium content from $11,215 \mathrm{mg} 100 \mathrm{~g}^{-1}$ in

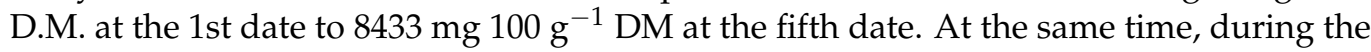
last harvest date, there was an increase in the amount of $\mathrm{Ca}$ in the plants, on average by $27.1 \%$ compared to the amount determined at all earlier dates. In addition, it was shown that plants with a longer growth period accumulated fewer nitrates.

It was proven that $\mathrm{Mg}$ and $\mathrm{Ca}$ accumulation was fostered by cultivation on medium soil with sowing at both dates, and on light soil with sowing done in spring. On both soil types, spring-sown quinoa contained the lowest $P$. The interaction of these two factors did not significantly affect the amount of potassium and nitrate. However, a trend of decreasing the amount of $\mathrm{N}^{-\mathrm{NO}_{3}}$ in summer-sown plants in both medium and light soil was noticeable.

Statistical analysis showed no effect of the experiment factors on Ca:Mg molar ratio (Table 7). There was also no effect of soil type on the value of the other calculated ratios. We found, however, that plants sown in spring were characterized by significantly higher 
values of $\mathrm{Ca}: \mathrm{P}, \mathrm{K}: \mathrm{Mg}$ and $\mathrm{K}:(\mathrm{Mg}+\mathrm{Ca})$ molar ratios. It was also observed that the highest value of $\mathrm{Ca}: \mathrm{P}$ and at the same time the lowest $\mathrm{K}: \mathrm{Mg}$ and $\mathrm{K}:(\mathrm{Mg}+\mathrm{Ca})$ occurred in plants harvested at the last date, on average after about 60 days from the day of sowing. The value of $\mathrm{K}: \mathrm{Mg}$ and $\mathrm{K}:(\mathrm{Mg}+\mathrm{Ca})$ ratio was recorded at the same level of significance in plants harvested one week earlier. The cultivation of quinoa on light soil in summer resulted indeed in the lowest value of Ca:P ratio, and on medium soil in spring resulted in the highest value of $\mathrm{K}: \mathrm{Mg}$ and $\mathrm{K}:(\mathrm{Mg}+\mathrm{Ca})$.

Table 7. The effect of soil type, sowing date and harvest date on quinoa minerals molar ratio. Average from years $2015-2017$.

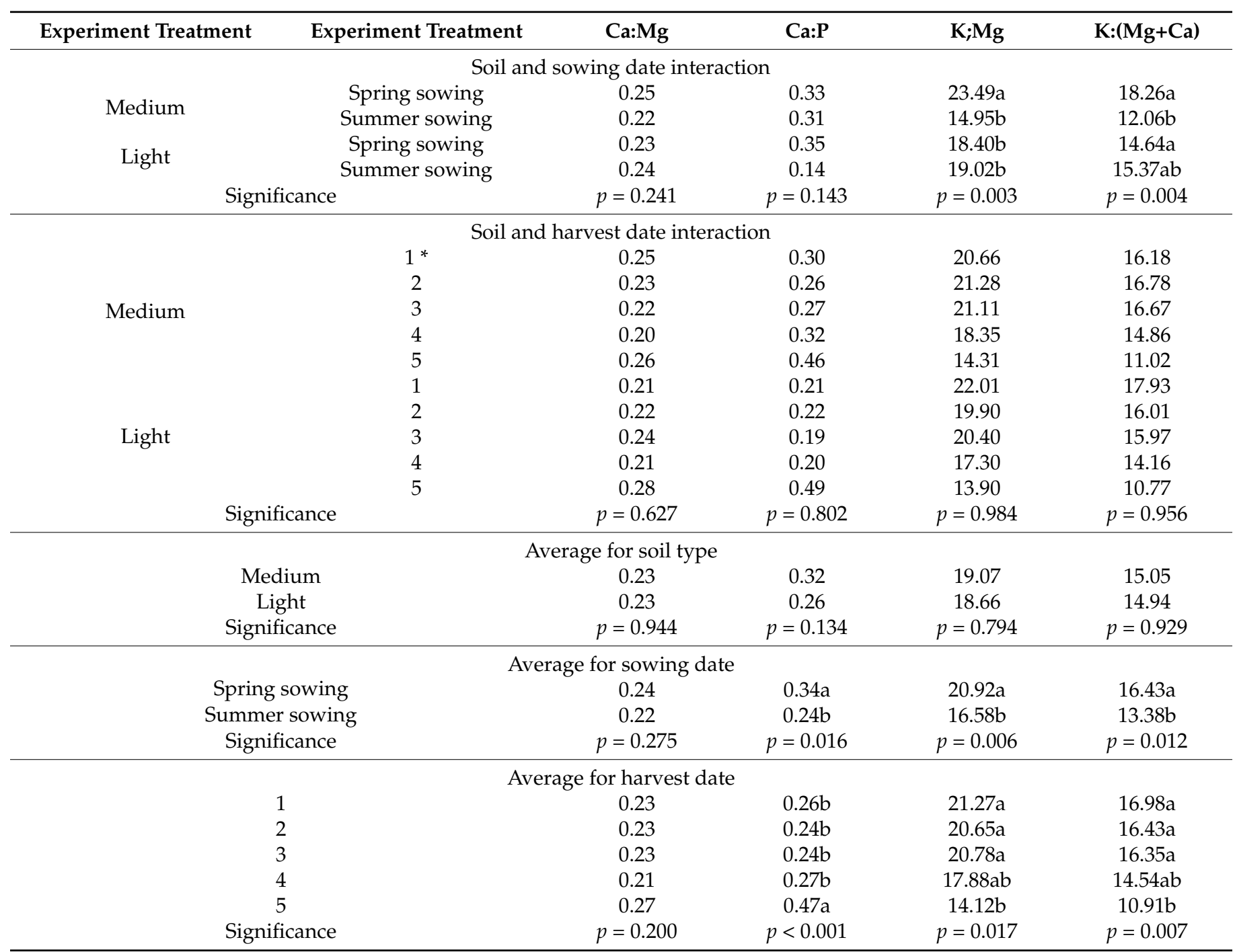

* explanation in Table 1, $p$-significance; similar small letter within each column indicate no significance differences between treatments $(p>0.05)$ based on results of ANOVA.

\section{Discussion}

Quinoa is considered a species with low soil requirements, recommended for cultivation on marginal soils [18]. In a study conducted by Rao and Shahid [32], quinoa showed high suitability for cultivation under desert conditions of the Arabian Peninsula, on sandy soil with neutral $\mathrm{pH}$ using spot irrigation with saline water at the rate of $4 \mathrm{~L}$ per day per plant. In our own study, under non-irrigated conditions, quinoa showed a very strong response to soil conditions. On the light soil in 2015 , conditions were extremely unfavorable at the summer sowing date; the drought occurring had a limiting effect on initial plant growth. On average for the entire study period, growing quinoa on medium soil provided a 4 times higher biomass yield of young shoots with leaves than that obtained from light 
soil. The spring sowing date was more favorable than the summer sowing date, and a statistically significant higher biomass yield of $56 \%$ was obtained. The plants from the summer sowing, on the other hand, were statistically more leafy. There is little information in the literature on the effect of soil type or sowing date, as well as harvesting date on quinoa biomass production.

Both quinoa sprouts and microgreens, as well as plants in early stages of development, are recommended for vegetable production purposes [7,12]. In the study by Pathan et al. [13], leafy quinoa shoots were harvested one month after sowing. El-Nagar et al. [33] recommends harvesting at 40 days after sowing. At a similar date (at 45 days after sowing), quinoa was harvested in a study conducted by Abd El-Samad et al. [12]. In our investigation, the harvesting date was a parameter of the experiment and depended on the weather pattern and sowing date at 23-40 days after sowing (1st harvesting date), to 50-69 days after sowing at the last (5th) harvesting date. With spring sowing applied, at the last harvest date, quinoa was at the beginning of inflorescence formation, which corresponded to the harvest date of the top part of the plants as the so-called quelite. Quinoa at this harvest date has a high nutritional value and is used in Mexico [34]. Inflorescence formation did not occur at the summer sowing date.

In the study conducted within our own research, at the third harvest date, i.e., at approximately 36-54 days after sowing, plants gained an average height of $23.2 \mathrm{~cm}$, which corresponded to the parameters of quinoa harvested under the climatic conditions of Egypt, at a similar period (at 40 days after sowing) [33]. In another study [12], quinoa was 28-36 cm tall at 45 days after sowing, which corresponded to the plants harvested in our study, at the 4th-5th date (at 45-69 days after sowing).

In our study, all experimental factors significantly affected the yield of the obtained biomass. The greatest variation was observed between harvest dates (on average from $220 \mathrm{~g}$ per $\mathrm{m}^{2}$ at the 1 st date to $1233 \mathrm{~g}$ per $\mathrm{m}^{2}$ at the 5 th date). The biomass yield of quinoa on light soil was on average 35-51\% lower than in the study of El-Naggar [33], while on medium soil, a 96-162\% higher yield was obtained than in the study conducted under northern Egyptian conditions, on clay and sandy soil. Significantly higher quinoa yields (2.0-4.1 $\mathrm{kg}$ per $\left.\mathrm{m}^{2}\right)$ were found in the study of Abd El-Samad [12]. During the winter season and following irrigation under Ganges Plain (Uttar Pradesh) conditions, quinoa was harvested $40-85$ days after sowing and the yield obtained ranged from $0.15-0.72 \mathrm{~kg}$ per $\mathrm{m}^{2}$ [35].

There have been a few studies on chemical composition and nutritional value showing that quinoa harvested at the vegetative stage is a valuable unconventional vegetable that can be used in human nutrition [13]. Based on their study, the authors showed that quinoa harvested during early vegetative development has high protein content with good amino acid composition and high mineral content. Vazquez et al. [7] also highlight the high nutritional value of quinoa leaves, noting the high amount of mineral compounds and vitamins. In our study, quinoa was characterized by high and varied contents of K (from 8-11 g per $100 \mathrm{~g}$ DM), Mg (from 0.38-0.58 g per $100 \mathrm{~g}$ D.M.) and P (0.37-0.60 g per 100 g D.M.). Similar results were obtained by Pathan et al. [13] and respectively potassium and phosphorus contents were 8769 and $405 \mathrm{mg}$ per $100 \mathrm{~g}$ D.M. In the study of Abd El-Samad et al. [12], potassium content was lower at about $6 \%$, phosphorus at a similar level $(0.46 \%)$, while magnesium content was higher $(2.12 \%)$ than in our study.

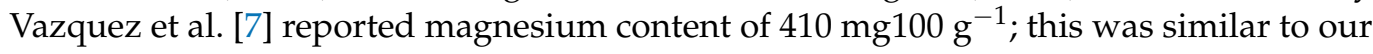
own study. Pathan et al. [13] point out that the variation may be due to the different conditions under which the study is conducted, the experimental variants used, as well as the analytical methods used.

One example of high variability is that of dry matter content. In the study by Pathan et al. [13], the dry matter content was relatively low at about 5\%. Abd El-Samad et al. [12] found that it ranged from 10.6-13.4\% in the quinoa that they analyzed. In our study, the D.M. content at harvest was at a similar level and ranged from $10.8-15.0 \%$ and showed statistical differences depending on sowing date and harvest date. Between the 1st and the 5 th date of harvest, an increase in the dry matter content by 3.2 percentage points 
(p.p.) was observed, while at the same time, there was a clear tendency for a decrease in the content of potassium (by 25\%) and phosphorus (by 21\%).

In the diet of mammals, including humans, the molar ratios between individual macronutrients play an important role [36]. The optimal molar ratio of macronutrients should not exceed: Ca:P-2, Ca:Mg-3, K:(Ca+Mg)-1.6-2.2, K:Mg-6, K:Ca-2. The high potassium content of quinoa results in an overly broad ratio of $\mathrm{K}:(\mathrm{Ca}+\mathrm{Mg})$ and $\mathrm{K}: \mathrm{Mg}$. Among the major factors contributing to the widespread occurrence of high blood pressure are unbalanced amounts of minerals: $\mathrm{Na}, \mathrm{K}, \mathrm{Ca}$ and $\mathrm{Mg}$ [37]. On average, a typical person with a $2100 \mathrm{kcal}$ of energy intake consumes $3000 \mathrm{mg} \mathrm{Na}, 1750 \mathrm{mg} \mathrm{K}, 440 \mathrm{mg}$ Ca and $180 \mathrm{mg}$ $\mathrm{Mg}$ [38]. In an energy-equivalent natural diet, the macronutrient ratios were different: $500,7400,1100$, and $800 \mathrm{mg}$ for $\mathrm{Na}, \mathrm{K}, \mathrm{Ca}$, and $\mathrm{Mg}$, respectively [38]. As the study shows, quinoa as a natural dietary ingredient can be a dietary source of potassium and magnesium, which are deficient in the human body.

Quinoa leaves also represent a source of bioactive compounds that can be used for food biofortification [16,39]. In our study, the content of polyphenols ranged from 106-143 mg-100g ${ }^{-1}$ f.m., vitamin C from $72-93 \mathrm{mg}-100 \mathrm{~g}^{-1}$ f.m., and carotenoids from 1.3-1.7 $\mu^{-1} \mathrm{~g}^{-1}$ f.m. In the study conducted by Nirmala and Prabhakar [40], the content of vitamin C was much lower and it was $8.8 \mathrm{mg}^{100 \mathrm{~g}^{-1}}$, while the content of carotenoids was higher-63.0-68.0 mg $100 \mathrm{~g}^{-1}$. In the study carried out by Gawlik-Dziki et al. [16], the content of polyphenols was higher and it amounted to $12.2-16.6 \mathrm{mg}^{-\mathrm{g}^{-1}} \mathrm{f}$.m.

\section{Conclusions}

Despite its low soil requirements, quinoa has exhibited a strong response to soil conditions and cultivation without irrigation on sandy soil. On light soil, during periods of drought when the Selianinov index is below 0.5, quinoa cultivation is at high risk. Based on the research of other authors in such soil conditions, it is necessary to plan the crop with irrigation, especially in the early growing season.

By deciding to grow quinoa in open field conditions, it is possible to ensure the supply of this alternative leafy vegetable species with high nutritional value for a significant part of the season (from late May to early July and from late August to early October). At the summer sowing date, quinoa can be harvested sooner at $3-4$ weeks after sowing, but the yield of biomass obtained is significantly lower thereafter.

In the early stages of development, when quinoa is harvested at the 1st or 2nd date (after 23-47 days), the yield obtained is low, poorly leafed and with high $\mathrm{N}-\mathrm{NO}_{3}$, potassium and phosphorus content. It is necessary to determine to which age groups of people and in what amounts the quinoa characterized by high content of phosphorus and potassium and at the same time containing high amounts of nitrates can be fed. However, due to the rich chemical composition, quinoa leaves (e.g., dried) can be treated as a biofortifying additive, increasing the value of basic food products. On the basis of the presented studies, the best time for harvesting of quinoa is 36-62 days after sowing, the more so because, as was proven, the content of biologically active compounds does not depend so much on the harvest date.

Author Contributions: Conceptualization, K.A.-S., J.S.; methodology, K.A.-S., J.S.; software, K.A.-S. and J.S.; validation J.S. and A.J.-R.; formal analysis, K.A.-S.; investigation, K.A.-S., J.S., A.J.-R.; resources, K.A.-S.; data curation, K.A.-S. and J.S.; writing-original draft preparation, K.A.-S. and J.S.; writing-review and editing, K.A.-S., A.J.-R.; visualization, K.A.-S. and J.S.; supervision, J.S.; project administration, K.A.-S. and J.S.; funding acquisition, K.A.-S. and J.S. All authors have read and agreed to the published version of the manuscript.

Funding: This research received no external funding. Wroclaw University of Environmental and Life Sciences founded the field research and analysis.

Institutional Review Board Statement: Not applicable for studies not involving humans or animals.

Informed Consent Statement: Not applicable. 


\section{Data Availability Statement: Not applicable.}

Conflicts of Interest: The authors declare no conflict of interest.

\section{References}

1. FAO/WHO. Quinoa: An Ancient Crop to Contribute to World Food Security. Regional Office for Latin America and the Caribbean. 2011. Available online: http:/ / www.fao.org/3/aq287e/aq287e.pdf (accessed on 3 February 2021).

2. Jacobsen, S.-E. The Worldwide Potential for Quinoa (Chenopodium quinoa Willd.). Food Rev. Int. 2003, 19, 167-177. [CrossRef]

3. Bonifacio, A. Chenopodium Sp.: Genetic Resources, Ethnobotany, and Geographic Distribution. Food Rev. Int. 2003, 19, 1-7. [CrossRef]

4. National Research Council. Lost Crops of the Incas: Little-Known Plants of the Andes with Promise for Worldwide Cultivation; The National Academies Press: Washington, DC, USA, 1989. Available online: https://doi.org/10.17226/1398 (accessed on 5 February 2021).

5. Bazile, D.; Baudron, F. The dynamics of the global expansion of quinoa growing in view of its high biodiversity. In $F A O \mathcal{E} C I R A D$. State of the Art Report of Quinoa in the World in 2013; FAO: Rome, Italy, 2015; Chapter 1.4, pp. 42-55.

6. FAOSTAT. 2019. Available online: http://www.fao.org/faostat/en/\#data/QC (accessed on 3 February 2021).

7. Vázquez-Luna, A.; Veracruzana, U.; Cortés, V.P.; Carmona, F.F.; Díaz-Sobac, R.; De Chile, P.U.C. Quinoa leaf as a nutritional alternative. Cienc. Investig. Agrar. 2019, 46, 137-143. [CrossRef]

8. Bhargava, A.; Shukla, S.; Ohri, D. Genetic variability and interrelationship among various morphological and quality traits in quinoa (Chenopodium quinoa Willd.). Field Crop. Res. 2007, 101, 104-116. [CrossRef]

9. Poonia, A.; Upadhayay, A. Chenopodium album Linn: Review of nutritive value and biological properties. J. Food Sci. Technol. 2015, 52, 3977-3985. [CrossRef] [PubMed]

10. Santiago-Saenz, Y.O.; Hernández-Fuentes, A.D.; Monroy-Torres, R.; Cariño-Cortés, R.; Jiménez-Alvarado, R. Physicochemical, nutritional and antioxidant characterization of three vegetables (Amaranthus hybridus L., Chenopodium berlandieri L., Portulaca oleracea L.) as potential sources of phytochemicals and bioactive compounds. J. Food Meas. Charact. 2018, 12, 2855-2864. [CrossRef]

11. Velázquez-Ibarra, A.; Covarrubias-Prieto, J.; Ramírez-Pimentel, J.; Aguirre-Mancilla, C.; Iturriaga de la Fuente, G.; Raya-Pérez, J. Nutritional quality of Mexican quelites (Green leafy). Cienc. Tecnol. Agropecu. 2016, 4, 1-9.

12. Abd El-Samad, E.H.; Hussin, S.A.; El-Naggar, A.M.; El-Bordeny, N.E.; Eisa, S.S. The potential use of quinoa as a new nontraditional leafy vegetable crop. Biosci. Res. 2018, 15, 3387-3403.

13. Pathan, S.; Eivazi, F.; Valliyodan, B.; Paul, K.; Ndunguru, G.; Clark, K. Nutritional Composition of the Green Leaves of Quinoa (Chenopodium quinoa Willd.). J. Food Res. 2019, 8, 55. [CrossRef]

14. Mlakar, S.G.; Turinek, M.; Jakop, M.; Bavec, M.; Bavec, F. Grain amaranth as an alternative and perspective crop in temperate climate. J. Geogr. 2010, 5, 135-145.

15. Paśko, P.; Bartoń, H.; Zagrodzki, P.; Gorinstein, S.; Fołta, M.; Zachwieja, Z. Anthocyanins, total polyphenols and antioxidant activity in amaranth and quinoa seeds and sprouts during their growth. Food Chem. 2009, 115, 994-998. [CrossRef]

16. Gawlik-Dziki, U.; Dziki, D.; Świeca, M.; Sęczyk, Ł.; Różyło, R.; Szymanowska, U. Bread enriched with Chenopodium quinoa leaves powder-The procedures for assessing the fortification efficiency. LWT 2015, 62, 1226-1234. [CrossRef]

17. Tang, Y.; Tsao, R. Phytochemicals in quinoa and amaranth grains and their antioxidant, anti-inflammatory, and potential health beneficial effects: A review. Mol. Nutr. Food Res. 2017, 61, 1-16. [CrossRef] [PubMed]

18. Choukr-Allah, R.; Rao, N.K.; Hirich, A.; Shahid, M.; Alshankiti, A.; Toderich, K.; Gill, S.; Butt, K.U.R. Quinoa for Marginal Environments: Toward Future Food and Nutritional Security in MENA and Central Asia Regions. Front. Plant Sci. 2016, 7, 1-11. [CrossRef]

19. Hirich, A.; Choukr-Allah, R.; Jelloul, A.; Jacobsen, S.-E. Quinoa (Chenopodium quinoa Willd.) seedling, water uptake and yield responses to irrigation water salinity. Acta Hortic. 2014, 1054, 145-152. [CrossRef]

20. Hirich, A.; Jelloul, A.; Choukr-Allah, R.; Jacobsen, E.S. Saline Water Irrigation of Quinoa and Chickpea: Seedling Rate, Stomatal Conductance and Yield Responses. J. Agron. Crop. Sci. 2014, 200, 378-389. [CrossRef]

21. Kabała, C.; Charzyński, P.; Bednarek, R. Światowa baza referencyjna zasobów glebowych 2014. In Międzynarodowy System Klasyfikacji Gleb; Food and Agriculture Organization of the United Nations by Polish Society of Soil Science: Rome, Italy, 2015. Available online: http://ptg.sggw.pl/wp-content/uploads/2020/11/WRB_2015full.pdf (accessed on 18 April 2021). (In Polish)

22. Adamczewska-Sowińska, K.; Sowiński, J. Reaction of Sweet Maize to the Use of Polyethylene Film and Polypropylene Non-Woven Fabric in the Initial Growth Phase. Agronomy 2020, 10, 141. [CrossRef]

23. Kaczmarek, Z.; Glina, B. Physical and water properties of arable soils located in the area of a predicted depression cone of "Tomisławice" lignite open-cast mine (central Poland). Pol. J. Soil Sci. 2018, 50, 167. [CrossRef]

24. Głąb, L.; Sowiński, J. Sustainable Production of Sweet Sorghum as a Bioenergy Crop Using Biosolids Taking into Account Greenhouse Gas Emissions. Sustainability 2019, 11, 3033. [CrossRef]

25. Fruit and Vegetable Products_Preparation of Samples and Testing Methods_Determination of Dry Matter Content by Gravimetric Method; PN-90/A-75101/03; Wydawnictwa Normalizacyjne Alfa Warsaw: Warsaw, Poland, 1990. (In Polish)

26. Fruit and Vegetable Products_Preparation of Samples and Testing Methods_Determination of Ascorbic Acid Content; PN-90/A-75101/11; Wydawnictwa Normalizacyjne Alfa Warsaw: Warsaw, Poland, 1990. (In Polish)

27. Slinkard, K.; Singleton, V.L. Total phenol analysis: Automation and comparison with manual method. Am. J. Enol. Vitic. 1977, $28,49-55$. 
28. Sowiński, J.; Głąb, L. The effect of nitrogen fertilization management on yield and nitrate contents in sorghum biomass and bagasse. Field Crop. Res. 2018, 227, 132-143. [CrossRef]

29. Casini, P. Seed yield of two new quinoa (Chenopodium quinoa Willd.) breeding lines as affected by sowing date in Central Italy. Acta Agric. Slov. 2019, 113, 51-62. [CrossRef]

30. Faligowska, A.; Panasiewicz, K.; Szymańska, G.; Ratajczak, K.; Sulewska, H.; Pszczółkowska, A.; Kocira, A. Influence of Farming System on Weed Infestation and on Productivity of Narrow-Leaved Lupin (Lupinus angustifolius L.). Agriculture 2020, 10, 459. [CrossRef]

31. Podleśna, A.; Podlesny, J.; Doroszewski, A. Usefulness of selected weather indices to evaluation of yellow lupine yielding possibility. Agric. Water Manag. 2014, 146, 201-207. [CrossRef]

32. Rao, N.K.; Shahid, M. Quinoa-A promising new crop for the Arabian Peninsula. American-Eurasian. J. Agric. Environ. Sci. 2012, 12, 1350-1355. [CrossRef]

33. El-Naggar, A.M.; Hussin, S.A.; El-Samad, E.A.; Eisa, S.S. Quinoa as a new leafy vegetable crop in Egypt. Arab. Univ. J. Agric. Sci. 2018, 26, 745-753. [CrossRef]

34. Santiago-Saenz, Y.O.; Hernández-Fuentes, A.D.; López-Palestina, C.U.; Garrido-Cauich, J.H.; Alatorre-Cruz, J.M.; Mon-roy-Torres, R. Nutritional importance and biological activity of bioactive compounds from quelites consumed in Mexico. Rev. Chil. Nutr. 2019, 46, 593-605. [CrossRef]

35. Bhargava, A.; Shukla, S.; Ohri, D. Effect of sowing dates and row spacings on yield and quality components of quinoa (Chenopodium quinoa) leaves. Indian J. Agr. Sci. 2007, 77, 748-751.

36. Francke, A.; Klasa, A. The Effect of Cultivation Method on the Macronutrients Content of Shallot Bulbs (Allium ascalonicum L.). J. Fruit Ornam. Plant Res. 2009, 70, 163-171. [CrossRef]

37. Karppanen, P.K.M.L.; Mervaala, E. Why and how to implement sodium, potassium, calcium, and magnesium changes in food items and diets? J. Hum. Hypertens. 2005, 19, S10-S19. [CrossRef] [PubMed]

38. Eaton, S.B. Paleolithic vs. modern diets—slected pathophysiological implications. Eur. J. Nutr. 2000, 39, 67-70. [CrossRef] [PubMed]

39. Gawlik-Dziki, U.; Świeca, M.; Sułkowski, M.; Dziki, D.; Baraniak, B.; Czyż, J. Antioxidant and anticancer activities of Chenopodium quinoa leaves extracts-In vitro study. Food Chem. Toxicol. 2013, 57, 154-160. [CrossRef] [PubMed]

40. Nirmala, A.; Prabhakar, B.N. Performance of quinoa as leafy vegetable. Agric. Food E-Newsl. 2020, 2, 824-825. Available online: https:/ /www.researchgate.net/publication/346264513_Performance_of_Quinoa_as_leafy_vegetable (accessed on 3 February 2021). 